\title{
Inactivation of Listeria monocytogenes in ready-to-eat smoked turkey meat by combination with packaging atmosphere, oregano essential oil and cold temperature
}

\author{
Samir A. Mahgoub ${ }^{1 *}$, Rasha M. El-Mekkawy ${ }^{2}$, Mohamed E. Abd El-Hack ${ }^{3^{*}}$ D, Waleed R. El-Ghareeb ${ }^{4,5}$, \\ Gamaleldin M. Suliman ${ }^{6}$, Abdullah N. Alowaimer ${ }^{6}$ and Ayman A. Swelum,
}

\begin{abstract}
The effects of packaging atmosphere, storage temperature and oregano essential oil (EO) on growth of Listeria monocytogenes on ready-to-eat smoked turkey were studied. Smoked turkey slices were inoculated with a strain of Listeria monocytogenes Scott A (5.95, 5.28 and $5.26 \mathrm{log}$ CFU/g) then vacuum packaged (VP), modified atmosphere packaging (MAP: $40 \% \mathrm{CO}_{2}$ and $60 \% \mathrm{~N}_{2}$ ) and MAP with oregano essential oil (MAPEO), respectively. The treated slices were then stored at $0,5,10$ and $15^{\circ} \mathrm{C}$ for 179.88 days and the L. monocytogenes Scott A's growth and microbial shelf life were monitored. The combination of MAP or MAPEO and storage temperature did not allow growth of L. monocytogenes higher than log $1 \mathrm{CFU} / \mathrm{g}$ during all storage periods. While in VP temperature combinations, the multiplication of bacteria were $\geq 1 \log$ CFU/g. In VP, MAP and MAPEO smoked turkey, the growth of L. monocytogenes increased regardless of storage temperature. In MAPEO samples the inoculum in the product was suppressed by ca. $5 \mathrm{log}$ CFU/g at 0, 10 and $15^{\circ} \mathrm{C}$ at 180, 117 and 81 days of storage, respectively. The inhibition of L. monocytogenes in ready-to-eat smoked turkey by the combinations of MAP and MAPEO was enhanced by storage at 0 or $5^{\circ} \mathrm{C}$. The MAPEO system can be used effectively to control growth of pathogen in processed food when maintaining fixed temperature measures is difficult.
\end{abstract}

Keywords: Listeria monocytogenes, Smoked-turkey, Oregano, Packaging

\section{Introduction}

Recently, supplying high quality food is of high consideration in the world (Possas et al. 2017). Concerns are not only about factors such as pesticide and fertilizer use, or contamination with various types of other chemicals (Possas et al. 2017). A major concern is ensuring of food quality and safety with regard to the presence of harmful microorganisms. Many factors have contributed in the incidence the requirement for ethnic imported food, changing of manufacturing process, the expansion

\footnotetext{
*Correspondence: mahgoubsamir@gmail.com;

dr.mohamed.e.abdalhaq@gmail.com

${ }^{1}$ Microbiology Department, Faculty of Agriculture, Zagazig University,

Zagazig 44511, Egypt

${ }^{3}$ Poultry Department, Faculty of Agriculture, Zagazig University,

Zagazig 44511, Egypt

Full list of author information is available at the end of the article
}

of food industry, as well as changing in consumers customs, consumption of refrigerated or frozen ready-to-eat (RTE) food products. Moreover, improvements in retail and distribution practices as centralization of activities, internet shopping and global procurement lead to distant distribution points; hence extended storage periods for a variety of products with variable temperature and humidity requirements. All those lead to great demands for innovation in the field of food packaging industry. Smoked turkey products are ready-to-eat meat products and are commonly sold in vacuum packages with a refrigerated shelf life of 30-60 days. Sliced smoked turkey contains less than $2 \%$ salt and fat, $\mathrm{pH}$ higher than 6.00 and water activity $\left(\mathrm{a}_{\mathrm{w}}\right)$ approximately 0.96 . L. monocytogenes is a food born pathogen having the ability to survive and grow over harsh conditions such as temperature from zero to $45^{\circ} \mathrm{C}$, $\mathrm{pH}$ from 4.5 to 9 , and high 
salt concentration $(10 \% \mathrm{NaCl})$ (Grau and Vanderlinde 1990a, b). Listeriosis is considered a severe fatal disease in human (Mead 2004).

The critical factors which affect the behaviour of $L$. monocytogenes on modified atmosphere packaged meat include storing temperature, $\mathrm{pH}$, and tissue kind (lean or fat) as well as the background biota had no effect on its growth (Grau and Vanderlinde 1990a, b). After 30 days, no growth of L. monocytogenes was detected in turkey roll slices that were previously inoculated with $3 \log \mathrm{cfu} / \mathrm{g}$ of the pathogen then packaged in high-barrier bags with $70 \% \mathrm{CO}_{2}+30 \% \mathrm{~N}_{2}$ at either 4 or $10{ }^{\circ} \mathrm{C}$ (Farber and Daley 1994). On the other hand, 50:50 mixture of $\mathrm{CO}_{2}: \mathrm{N}_{2}$ showed a lesser inhibition.

In food systems, essential oils (Eos) play an important role as natural antimicrobials which can extend the shelf life of the products (Kalemba and Kunicka 2003; Burt and Reinders 2003; Burt 2004). They exert their effect through decreasing the stabilization of phospholipids bilayer of the cell membrane and modifying membrane permeability. Moreover, plant EOs modify enzymatic system and the genetic material of the bacteria with reduction of ATP production (Lambert et al. 2001; Ultee et al. 2002; Oussalah et al. 2006). The effect of various EOs against L. monocytogenes as well as the effect of other environmental factors on such activity have been investigated by Aureli et al. (1992).

Several trials have been done to inhibit the microbial growth in foods, including modifying atmosphere packaging and adding chemical preservatives (Holley and Patel 2005). Usage of an active antimicrobial packaging material is considered promising technique. The evaluation of the effects of vacuum packaged and modified atmosphere with or without essential oil packaged on $L$. monocytogenes inoculated in smoked turkey meat slices stored at $0,5,10$ and $15{ }^{\circ} \mathrm{C}$ was the aim of the present study. Realizing the behaviour of $L$. monocytogenes in different packaging type can afford crucial information that may be helpful to promote the shelf life and safety of minimally processed foods (Holley and Patel 2005).

\section{Materials and methods}

\section{Sampling procedure}

\section{Preparation of inoculum and inoculation of smoked turkey}

Listeria monocytogenes Scott A strain used in this investigation was obtained from Lab. Microbiology and Biotechnology of Foods, Department of Food Science and Human Nutrition, Era Odos 75, Athens 11855, Greece. L. monocytogenes Scott A was preserved in broth at $-80{ }^{\circ} \mathrm{C}$. Reactivation of the cultures, before starting our experiments, was made by three successive transfers in tryptic soy broth (Difco Laboratories) at $30{ }^{\circ} \mathrm{C}$ for $24 \mathrm{~h}$. Cells were collected by centrifugation $(14,000 \mathrm{rpm}$ for
10 min at $4{ }^{\circ} \mathrm{C}$ ), followed by washing three times and resuspended in Ringer's balanced solution (Lab M). The cell numbers were determined by surface plating on polymyxin-acriflavine-lithium chloride-ceftazidime-aesculin-mannitol agar (PALCAM, Biolife) in duplicate. After $48 \mathrm{~h}$ of incubation at $30{ }^{\circ} \mathrm{C}$, colonies were counted. A final inoculum was prepared by serial dilution in Ringer's solution based on the desired cell numbers.

The smoked turkey slices were inoculated with $0.1 \mathrm{ml}$ of 6-7 log CFU/ml populations of $L$. monocytogenes. The final cell count on turkey was ca. 5-6 log CFU/g. The VP smoked turkey samples were opened and after inoculation with the pathogen, or in the case of the control treatment without inoculation with the pathogen, were repackaged with VP, MAP $\left(40 \% \mathrm{CO}_{2}\right.$ and $\left.60 \% \mathrm{~N}_{2}\right)$ or MAPEO $\left(40 \% \mathrm{CO}_{2}\right.$ and $60 \% \mathrm{~N}_{2}$ in combination with oregano essential oil of $2 \%$ ) as described in 2.1.5. Packages from each treatment (VP, MAP or MAPEO) were divided into four groups then each group was stored at $0,5,10$ or $15{ }^{\circ} \mathrm{C}$ and enumerated for L. monocytogenes within 6 months.

\section{Microbiological analysis}

For microbiological analyses, $25 \mathrm{~g}$ of each sample were transferred aseptically to a stomacher bag (Sewared, London, UK); homogenised with $225 \mathrm{ml}$ of sterile Ringer's solution (Lab $100 \mathrm{Z}$ ) for $60 \mathrm{~s}$ with a stomacher (Lab. Blender 400; Seward Medical, London, UK) at room temperature. Decimal solution in Ringer's solution was prepared. Duplicate $1 \mathrm{ml}$ or $0.1 \mathrm{ml}$ samples of appropriate dilutions were poured or spread on non-selective or selective agar plates.

Determination was carried out as follows: total viable counts (TVC) on plate count agar (PCA; Merck, 1.05463) incubated at $25{ }^{\circ} \mathrm{C}$ for $72 \mathrm{~h}$; Lactic Acid Bacilli (LAB) on de Man, Rogosa, Sharpe (MRS Biolife) overlain with $5 \mathrm{ml}$ of the same medium and incubated at $25^{\circ} \mathrm{C}$ for $72 \mathrm{~h}$; Pseudomonas spp. on cetrimide-fucidin-cephaloridine (CFC) Agar (Lab M, supplemented with selective supplement X109) incubated at $25^{\circ} \mathrm{C}$ for $48 \mathrm{~h}$; B. thermosphacta on STAA agar (streptomycin sulphate, cycloheximide and thallous acetate agar; Oxoid M881) incubated at $30{ }^{\circ} \mathrm{C}$ for $72 \mathrm{~h}$; Enterobacteriaceae on Violet Red Bile Glucose Agar (VRBG, Biolife), with a double layer of the same medium incubated at $37{ }^{\circ} \mathrm{C}$ for $24 \mathrm{~h}$; enterococci on Kanamycin Aesculin Azide Agar (LAB M 106) incubated at $37^{\circ} \mathrm{C}$ for $48 \mathrm{~h}$, counting the brown colonies as enterococci and the black colonies as streptococci and L. monocytogenes or Listeria spp. on polymyxin-acriflavine-lithium chlorideceftazidime-aesculin-mannitol agar (PALCAM, Biolife) after incubation at $30^{\circ} \mathrm{C}$ for $48 \mathrm{~h}$.

The lowest detection limit of the previous experiments was $2 \log _{10}$ CFU/g except for LAB and Enterobacteriaceae 
for which the limit was $1 \log _{10} \mathrm{CFU} / \mathrm{g}$. The bacterial population (by $\log _{10} \mathrm{CFU} / \mathrm{g}$ ) is the mean of duplicate plates.

Technique of Listeria enrichment The procedure used for isolation of Listeria spp. was a two-stage enrichment procedure (ISO 11290). $25 \mathrm{~g}$ of sample were transferred aseptically to a stomacher bag; $225 \mathrm{ml}$ of primary enrichment broth (sterile half Fraser broth) were mixed and homogenized for $60 \mathrm{~s}$ at room temperature and then incubated at $30^{\circ} \mathrm{C}$ for $48 \mathrm{~h}$. Samples $(0.1 \mathrm{ml})$ of primary enrichment cultures was transferred into a secondary enrichment (10 ml sterile Fraser broth). After $24 \mathrm{~h}$ of incubation at $30^{\circ} \mathrm{C}, 0.1 \mathrm{ml}$ or loopful from the secondary enrichment were plated and streak on PALCAM agar at $30{ }^{\circ} \mathrm{C}$ for $48 \mathrm{~h}$. Typical colonies of Listeria spp. were grown on PLACAM agar for $48 \mathrm{~h}$ at $30^{\circ} \mathrm{C}$ were $1.5-2 \mathrm{~mm}$ in diameter, grey-green colonies with black sunken centres and black halos.

\section{Identification of Listeria}

Tryptone soya agar was used to subculture suspected colonies (Lab. M) and incubated for $24 \mathrm{~h}$ at $37{ }^{\circ} \mathrm{C}$. Listeria identification was based on Gram stain, catalase and oxidase reactions, motility at $25{ }^{\circ} \mathrm{C}, \beta$-haemolysis reaction, and biochemical identification using fermentation of D-xylose, L-rhamnose, $\alpha$-methyl-D-mannoside and D-mannitol (Allerberger 2003). To identify various fastidious strains, API-Listeria was used.

\section{Measurement of $\mathrm{pH}$ and redox potential}

The $\mathrm{pH}$ and redox potential values of the samples were determined at each sampling interval. Briefly, $25 \mathrm{~g}$ of the product sample were blended with $225 \mathrm{ml}$ sterile Ringer's solution for $60 \mathrm{~s}$. A pH meter (model RL150) and redox model $827 \mathrm{pH}$ Lab (Metrohm) were used for the $\mathrm{pH}$ measurement. The redox values were converted by the equation of Midgley and Torrence (1978) were reported as redox potential $(\mathrm{mV})$.

\section{Measurement of $\mathrm{CO}_{2}$ and $\mathrm{O}_{2}$}

$\mathrm{CO}_{2}$ and $\mathrm{O}_{2}$ percentages in the MAP and MAPEO were determined using a PBI Dansensor (ChekMate $9900 \mathrm{O}_{2} /$ $\mathrm{CO}_{2}$ ).

\section{Statistical analysis}

Obtained data were analysed and processed by Excel and transformed into log CFU/g for all experiments. Analysis of variance (ANOVA) was performed to determine the significant difference $(P<0.05)$ in microbial counts and $\mathrm{pH}$ value changes during storage at different temperatures for both types of products. Logarithmic means were separated by Tukey's multiple range test using SPSS 10.0 for Windows ${ }^{\mathrm{TM}}$.

\section{Results}

The effects of vacuum packaging and storage temperature on growth of Listeria monocytogenes Scott A (PALCAM) and indigenous microflora (PCA and MRS) in smoked turkey are presented in Fig. 1. Under VP samples (control), the TVC increased to higher than $7 \mathrm{log} \mathrm{CFU} / \mathrm{g}$ in the smoked turkey slices at $29,23,8.0$ and 5 days of storage at $0,5,10$ and $15{ }^{\circ} \mathrm{C}$, respectively.

Figure 2 shows the change in $\mathrm{pH}$ and redox values (Eh) of vacuum packaged smoked turkey stored at different temperatures and inoculated with Listeria monocytogenes Scott A. The effect of MAP on growth of indigenous microflora in smoked turkey stored at different temperatures is displayed in Fig. 3. Figure 4 shows the effect of MAP and essential oil on growth of indigenous microflora in smoked turkey stored at different temperatures. The survival of Listeria monocytogenes in VP, MAP and MAP-EO smoked turkey at (A, $0{ }^{\circ} \mathrm{C}$; B, $5{ }^{\circ} \mathrm{C} ; \mathrm{C}, 10^{\circ} \mathrm{C}$ and $\mathrm{D}, 15^{\circ} \mathrm{C}$ ) is shown in Fig. 5 .

Figure 6 presents the change of $\mathrm{pH}$ and redox values of modified atmosphere packaging smoked turkey without essential oil and stored at $\mathrm{A}, 0{ }^{\circ} \mathrm{C} ; \mathrm{B}, 5{ }^{\circ} \mathrm{C}$; $\mathrm{C}$, $10{ }^{\circ} \mathrm{C}$ and $\mathrm{D}, 15^{\circ} \mathrm{C}$.

The change of $\mathrm{pH}$ and redox values of modified atmosphere packaging smoked turkey with essential oil and stored at $\mathrm{A}, 0{ }^{\circ} \mathrm{C} ; \mathrm{B}, 5{ }^{\circ} \mathrm{C} ; \mathrm{C}, 10{ }^{\circ} \mathrm{C}$ and $\mathrm{D}, 15{ }^{\circ} \mathrm{C}$ is exhibited in Fig. 7.

\section{Discussion}

Growth of indigenous flora in vacuum packed smoked turkey stored under different temperatures

The LAB in the control samples steadily increased from $1.3 \log \mathrm{CFU} / \mathrm{g}$ to the spoilage limit (> $7 \log \mathrm{CFU} / \mathrm{g}$ ) at $50.95,22.91,10.5$ and 6.5 days of storage at $0,5,10$ and $15{ }^{\circ} \mathrm{C}$, respectively. In the samples treated with L. monocytogenes, the initial TVC in the VP smoked turkey was similar to the pathogen population of ca. $6 \log \mathrm{CFU} / \mathrm{g}$. TVC in smoked turkey reached the spoilage limit $(>7$ $\log \mathrm{CFU} / \mathrm{g}$ ) after 23, 8, 2.5 and 1.5 days of storage at 0 , 5,10 and $15^{\circ} \mathrm{C}$, respectively, while the LAB in the samples reached these levels after 29,12, 6 and 4 days of storage under the same conditions (Fig. 1).

Under MAP and MAPEO, the initial levels of LAB were ca. $5 \log \mathrm{CFU} / \mathrm{g}$. The LAB had similar patterns growth under MAP and MAPEO, and reached the spoilage limit after $11.75,4.75,1.63$ and 0.63 days of storage at 0,510 and $15^{\circ} \mathrm{C}$, respectively (Figs. 3, 4).

\section{Changes in the $\mathrm{pH}$ and redox values in smoked turkey under different storage temperatures}

The evaluation of $\mathrm{pH}$ and redox potential in smoked turkey showed similar patterns under the three packaging 

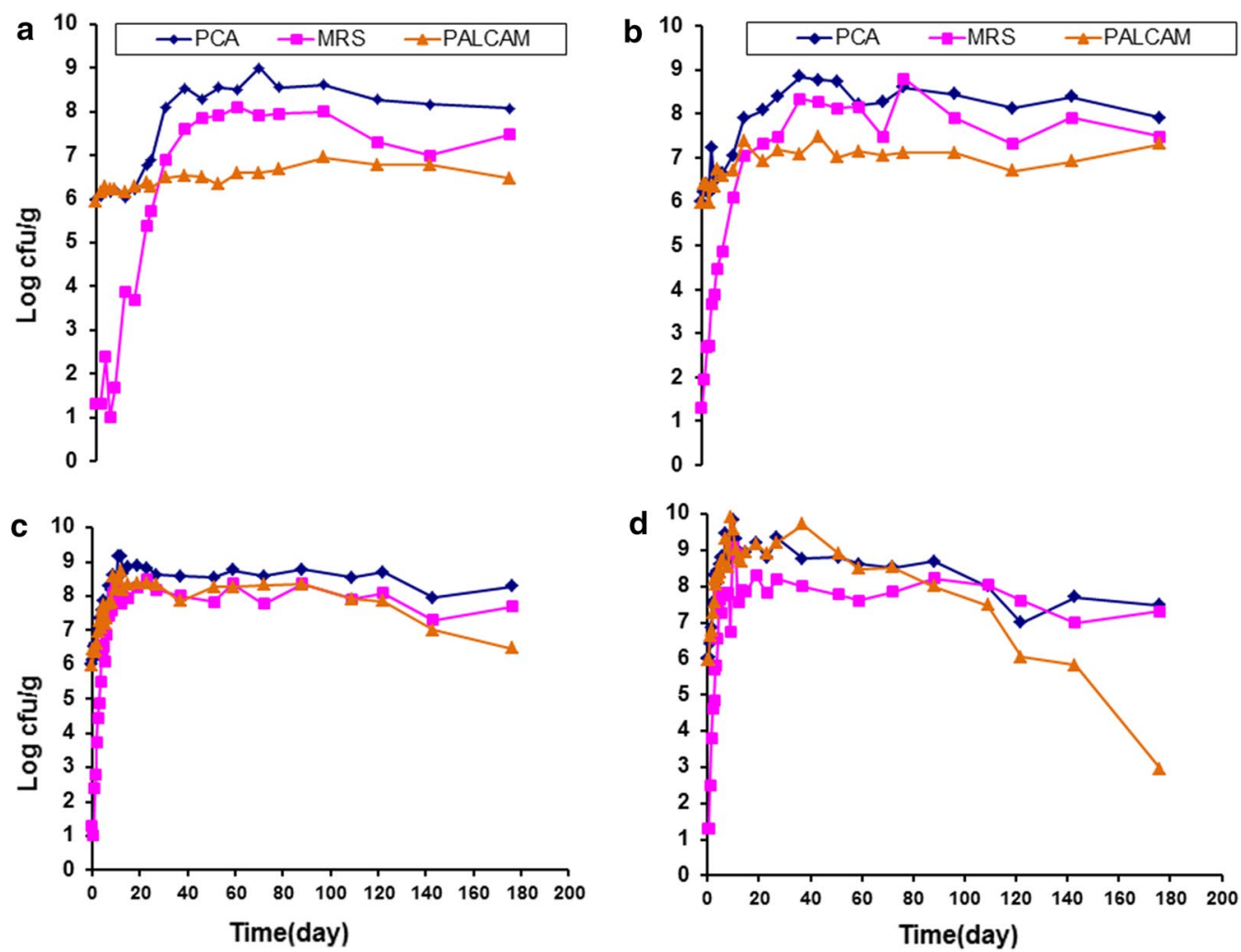

Fig. 1 Effect of vacuum packaging and storage temperature $\left(\mathbf{a} 0{ }^{\circ} \mathrm{C} ; \mathbf{b} 5^{\circ} \mathrm{C} ; \mathbf{c} 10^{\circ} \mathrm{C}\right.$ and $\left.\mathbf{d} 15^{\circ} \mathrm{C}\right)$ on growth of Listeria monocytogenes Scott A (PALCAM) and indigenous microflora (PCA and MRS) in smoked turkey

combinations and different temperature regimes. A slight change in $\mathrm{pH}$ and redox potential was observed during the shelf life of the product in all of the control and treated smoked turkey samples. At the end of storage, a high drop in the $\mathrm{pH}$ and high increase in redox potential were observed under all storage temperatures and packaging conditions (Figs. 3, 4, 6, 7).

\section{Changes in gases in MAP and MAPEO samples}

The concentration of gases in the packages throughout the storage period showed only little change from the beginning until the end of storage, highlighting the effectiveness of the mechanical barriers for gas exchange.

\section{The behaviour of $L$. monocytogenes in ready-to-eat (RTE) smoked turkey}

From the control experiment on smoked turkey (without inoculation of L. monocytogenes Scott A), no L. monocytogenes were found throughout the period of storage (96 days) at $0,5,10$ and $15{ }^{\circ} \mathrm{C}$, which demonstrate that L. monocytogenes was likely not initially present in the smoked turkey used. During the shelf life of the product inoculated with $L$. monocytogenes, the maximum increases in the growth of $L$. monocytogenes were by 0.54, 0.72 and $0.74 \log \mathrm{CFU} / \mathrm{g}$ at $0{ }^{\circ} \mathrm{C}, 0.78,0.20$ and 0.64 $\log \mathrm{CFU} / \mathrm{g}$ at $5{ }^{\circ} \mathrm{C}, 1.33 ; 0.72$ and $0.78 \log \mathrm{CFU} / \mathrm{g}$ at $10{ }^{\circ} \mathrm{C}$; and 2.41, 1.02 and $0.32 \log \mathrm{CFU} / \mathrm{g}$ ) at $15^{\circ} \mathrm{C}$, under packaging with VP, MAP and MAPEO, respectively (Fig. 5). The application of MAP and MAPEO is within the U.S. Department of Agriculture, Food Safety and Inspection Service (2004) guidelines as it did not allow the pathogen to increase by more than $1 \log \mathrm{CFU} / \mathrm{g}$ during the shelf life of the product, but the application of VP to samples did allow such an increase.

\section{Under vacuum packaging}

The initial level of the pathogen in the VP smoked turkey was $5.95 \log \mathrm{CFU} / \mathrm{g}$. The levels of $L$. monocytogenes increased to $\geq 7 \log$ CFU/g after 76, 23, 2.5 and 1.5 days of storage at $0,5,10$ and $15{ }^{\circ} \mathrm{C}$, respectively. Storage at 0 and $5{ }^{\circ} \mathrm{C}$ allowed slower growth of $L$. monocytogenes than at 10 and $15^{\circ} \mathrm{C}$, but it did not allow the pathogen to increase more than $1 \log \mathrm{CFU} / \mathrm{g}$, while storage at 10 and $15^{\circ} \mathrm{C}$ allowed the pathogen to increase by ca. $2 \log \mathrm{CFU} / \mathrm{g}$ during the shelf life of smoked turkey. The ability of $L$. monocytogenes to grow on VP raw and industrially processed (frankfurters) beef and pork meat has been documented by other studies (Grau and Vanderlinde 1990a, b; Porto et al. 2002; Samelis et al. 2002). Therefore, a combination of low-temperature storage in the presence of 

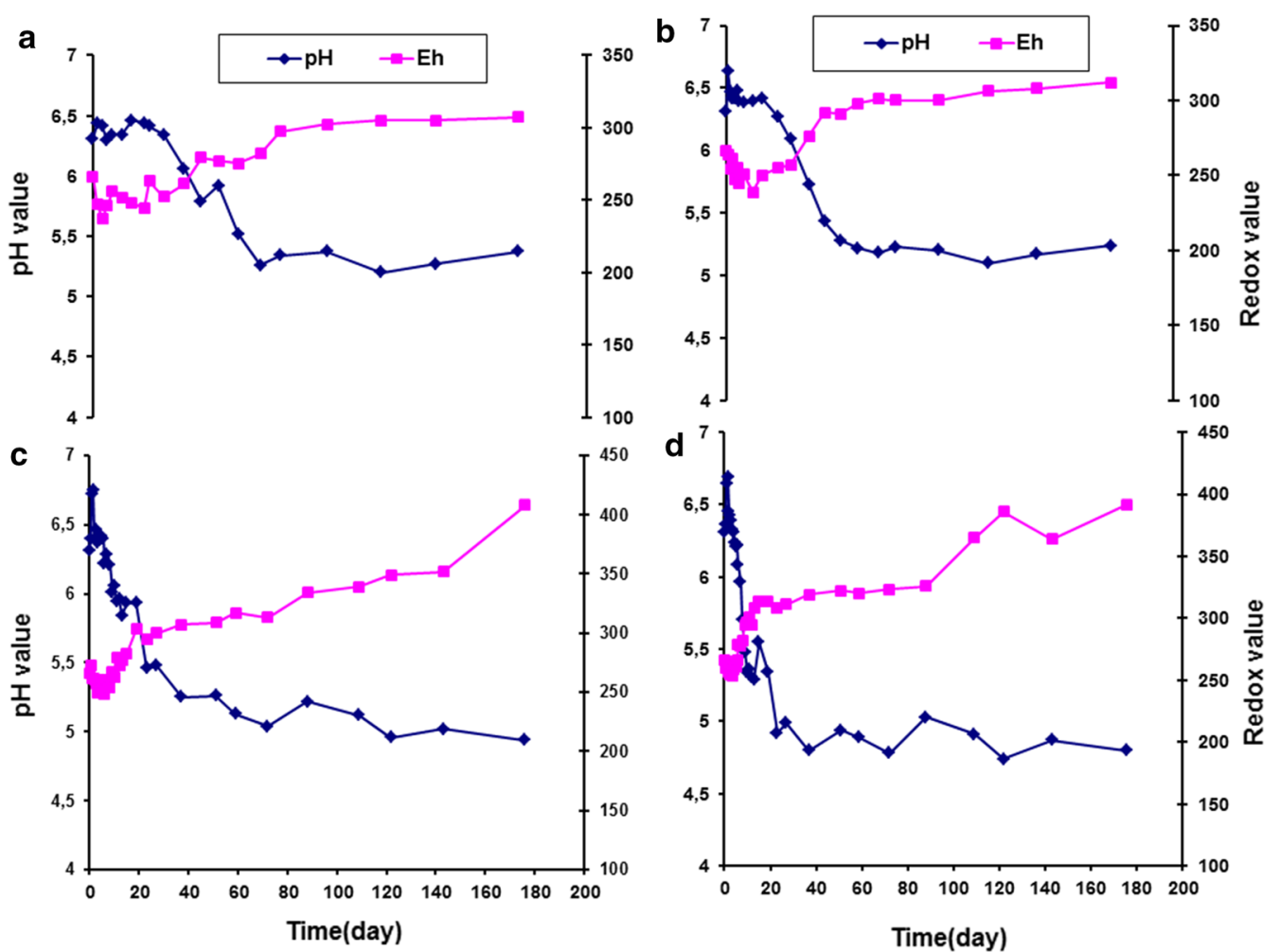

Fig. 2 Change of $\mathrm{pH}$ and redox values (Eh) of vacuum packaged smoked turkey storage at different temperature $\left(\mathbf{a} 0^{\circ} \mathrm{C} ; \mathbf{b} 5^{\circ} \mathrm{C} ; \mathbf{c} 10^{\circ} \mathrm{C}\right.$ and $\left.\mathbf{d ~} 15^{\circ} \mathrm{C}\right)$ and inoculated with Listeria monocytogenes Scott A
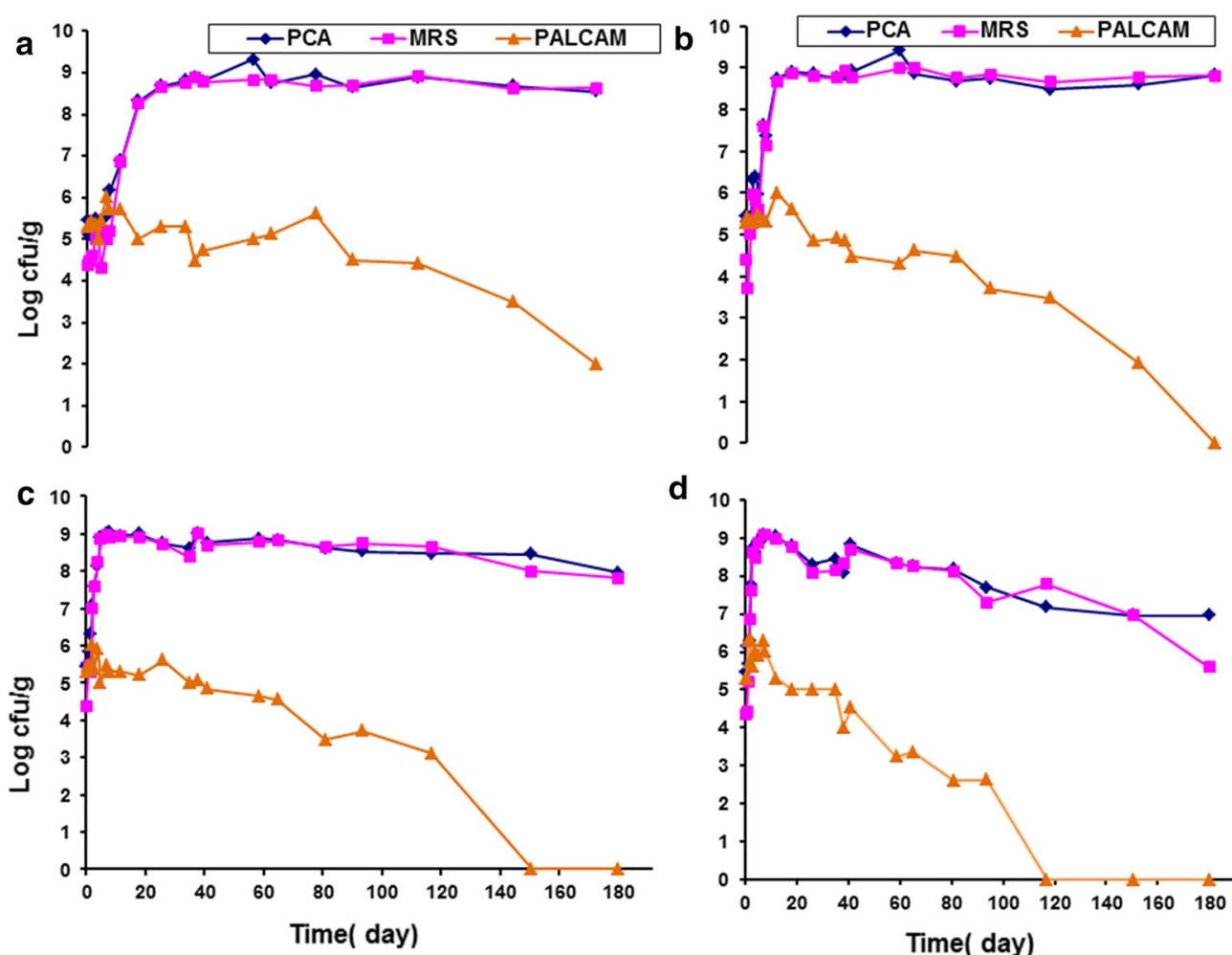

d

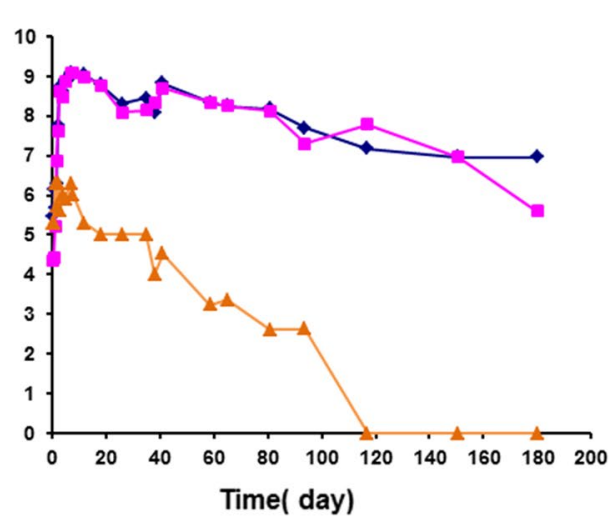

Fig. 3 Effect of MAP $\left(40 \% \mathrm{CO}_{2}+60 \% \mathrm{~N}_{2}\right.$ ) on growth of indigenous microflora (TVC, total viable count and LAB, lactic acid bacteria in smoked turkey storage at different temperature $\left(\mathbf{a} 0^{\circ} \mathrm{C} ; \mathbf{b} 5^{\circ} \mathrm{C} ; \mathbf{c} 10^{\circ} \mathrm{C}\right.$ and $\left.\mathbf{d} 15^{\circ} \mathrm{C}\right)$ 

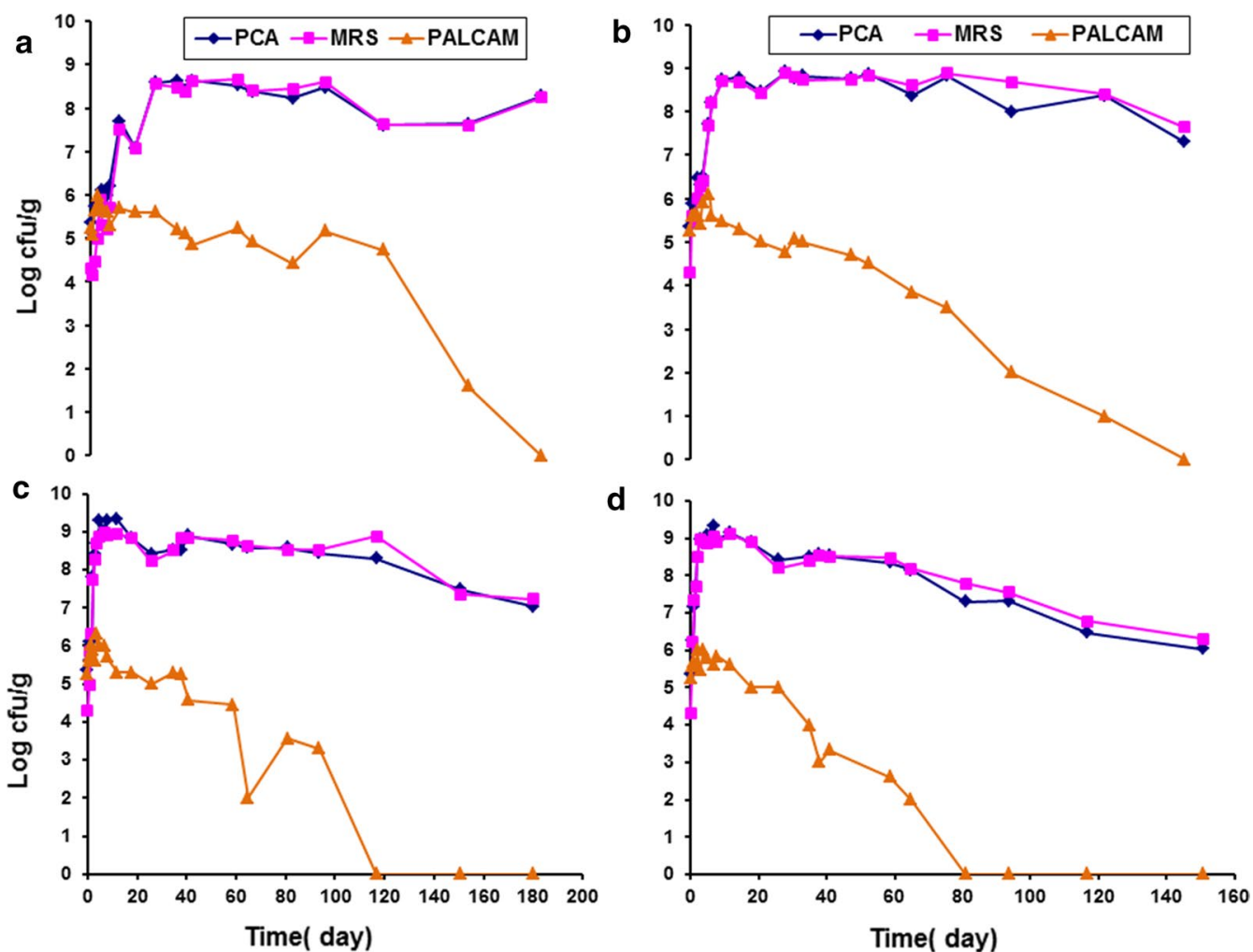

Fig. 4 Effect of MAP $\left(40 \% \mathrm{CO}_{2}+60 \% \mathrm{~N}_{2}\right)$ and essential oil on growth of indigenous microflora (TVC, total viable count and LAB, lactic acid bacteria in smoked turkey storage at different temperature $\left(\mathbf{a} 0{ }^{\circ} \mathrm{C} ; \mathbf{b} 5{ }^{\circ} \mathrm{C} ; \mathbf{c} 10^{\circ} \mathrm{C}\right.$ and $\left.\mathbf{d} 15^{\circ} \mathrm{C}\right)$

packaging film was found to provide suitable condition for the survival of $L$. monocytogenes on smoked turkey for a period longer than 5 months. Another study indicated that VP enhances the survival of L. monocytogenes on meat products compared to aerobic storage (unpackaged products), especially at low temperatures (Gounadaki et al. 2007).

\section{Under MAP}

The initial levels of the pathogen in the smoked turkey were $5.28 \mathrm{log} \mathrm{CFU} / \mathrm{g}$. Indeed, MAP smoked turkey did not allow the pathogen to increase in the product by $>1 \log \mathrm{CFU} / \mathrm{g}$ throughout the period of storage under all storage conditions. Rutherford et al. (2007) reported that $\mathrm{CO}_{2}$ packaging of ready-to-eat shrimp and storage at $3{ }^{\circ} \mathrm{C}$ not only had a great influence on growth of L. monocytogenes and other psychrotrophic bacteria but also increased the shelf life in comparison to vacuum packaging. In addition, storage temperatures higher than $3.3^{\circ} \mathrm{C}$ did not inhibit the pathogen. The combination of MAP with all the storage regimes seemed to effectively inhibit growth and cause the death of $L$. monocytogenes, whose numbers decreased by $>1 \log \mathrm{CFU} / \mathrm{g}$ after $116.83,80.83,64.83$ and 40.83 days of storage at $0,5,10$ and $15{ }^{\circ} \mathrm{C}$, respectively. Carbon dioxide inhibition of $L$. monocytogenes is effective even at abusive temperatures as illustrated by Avery et al. (1995).

\section{Under MAP with oregano essential oil}

The initial level of $L$. monocytogenes Scott A in the smoked turkey was $5.26 \log \mathrm{CFU} / \mathrm{g}$. The MAPEO samples under different storage temperatures did not permit the growth of $L$. monocytogenes by more than $\log 1 \mathrm{CFU} / \mathrm{g}$ throughout the period of storage. Under MAPEO, the inoculum in the product was suppressed by ca. $5 \log \mathrm{CFU} / \mathrm{g}$ ( 0 and 5), 10 and $15{ }^{\circ} \mathrm{C}$ after (150.79 days), 93.71 and 64.83 days of storage, respectively. A strong decrease in viable cells was noticed under MAPEO compared to MAP and VP under all temperatures. In another study by Mytle et al. (2006) on RTE frankfurters and clove essential oil, Scott A exhibited growth of $1.0 \log _{10}$ CFU/g in 14 days when a high inoculum of $6.0 \log _{10} \mathrm{CFU} / \mathrm{g}$ was applied at $5{ }^{\circ} \mathrm{C}$. In contrast, Hao et al. (1998a) observed no growth at high populations of L. monocytogenes (Scott A) in the controls at $5{ }^{\circ} \mathrm{C}$. Mytle et al. (2006) stated that the essential oil treatments exhibited a reduction in final $L$. monocytogenes populations at $5{ }^{\circ} \mathrm{C}$ and $15{ }^{\circ} \mathrm{C}$ storage as compared to the control in all treatments including Scott A. The essential oils do have greater effect in broth culture medium than in food as observed by Hao et al. (1998b). 

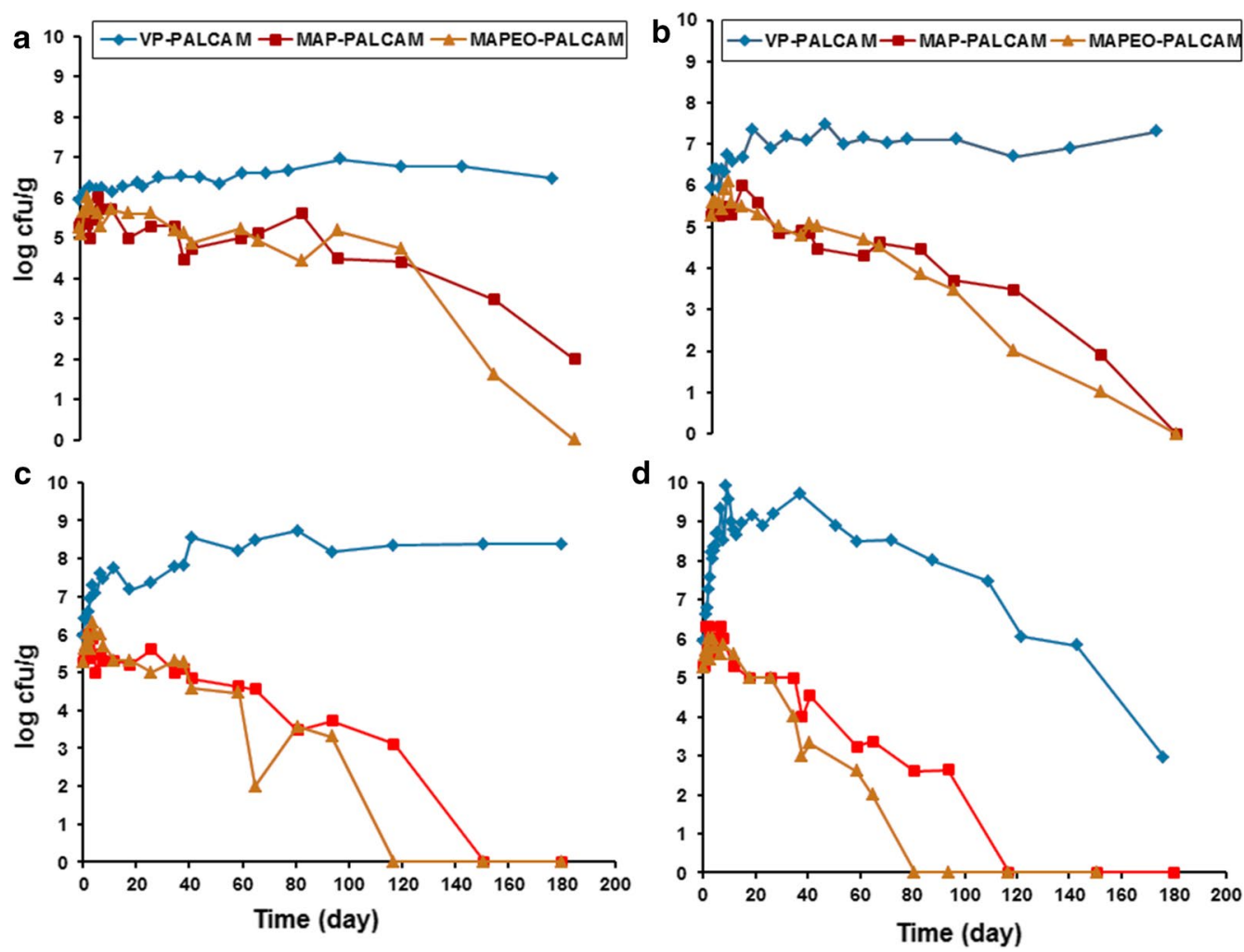

Fig. 5 Survival of Listeria monocytogenes in VP, MAP and MAP-EO smoked turkey at a $0{ }^{\circ} \mathrm{C} ; \mathbf{b} 5{ }^{\circ} \mathrm{C} ; \mathbf{c} 10^{\circ} \mathrm{C}$ and $\mathbf{d} 15^{\circ} \mathrm{C}$
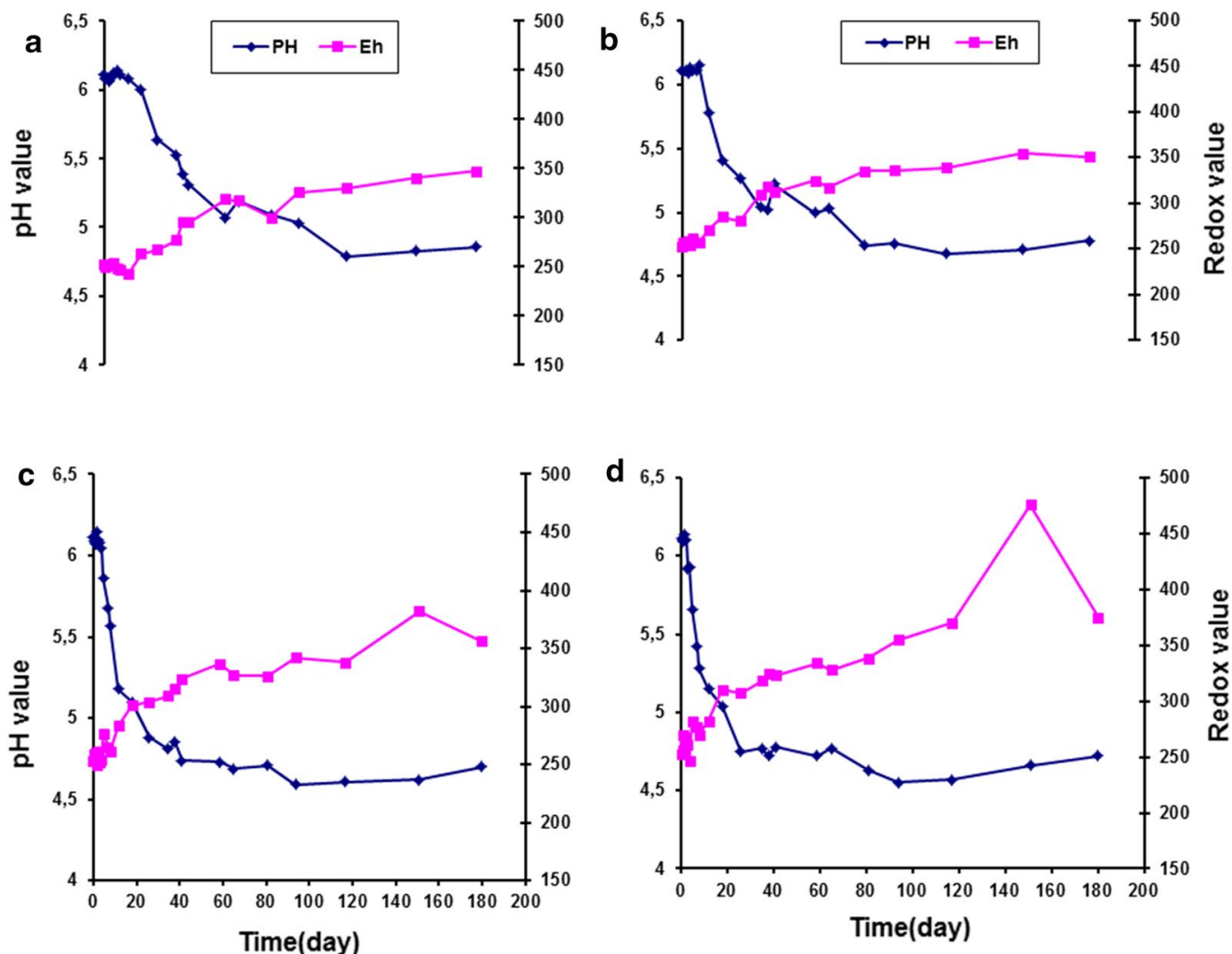

Fig. 6 Change of pH and redox values of modified atmosphere packaging smoked turkey without essential oil and stored at $\mathbf{a}, 0^{\circ} \mathrm{C} ; \mathbf{b} 5{ }^{\circ} \mathrm{C} ; \mathbf{c} 10^{\circ} \mathrm{C}$ and $\mathbf{d} 15^{\circ} \mathrm{C}$ 

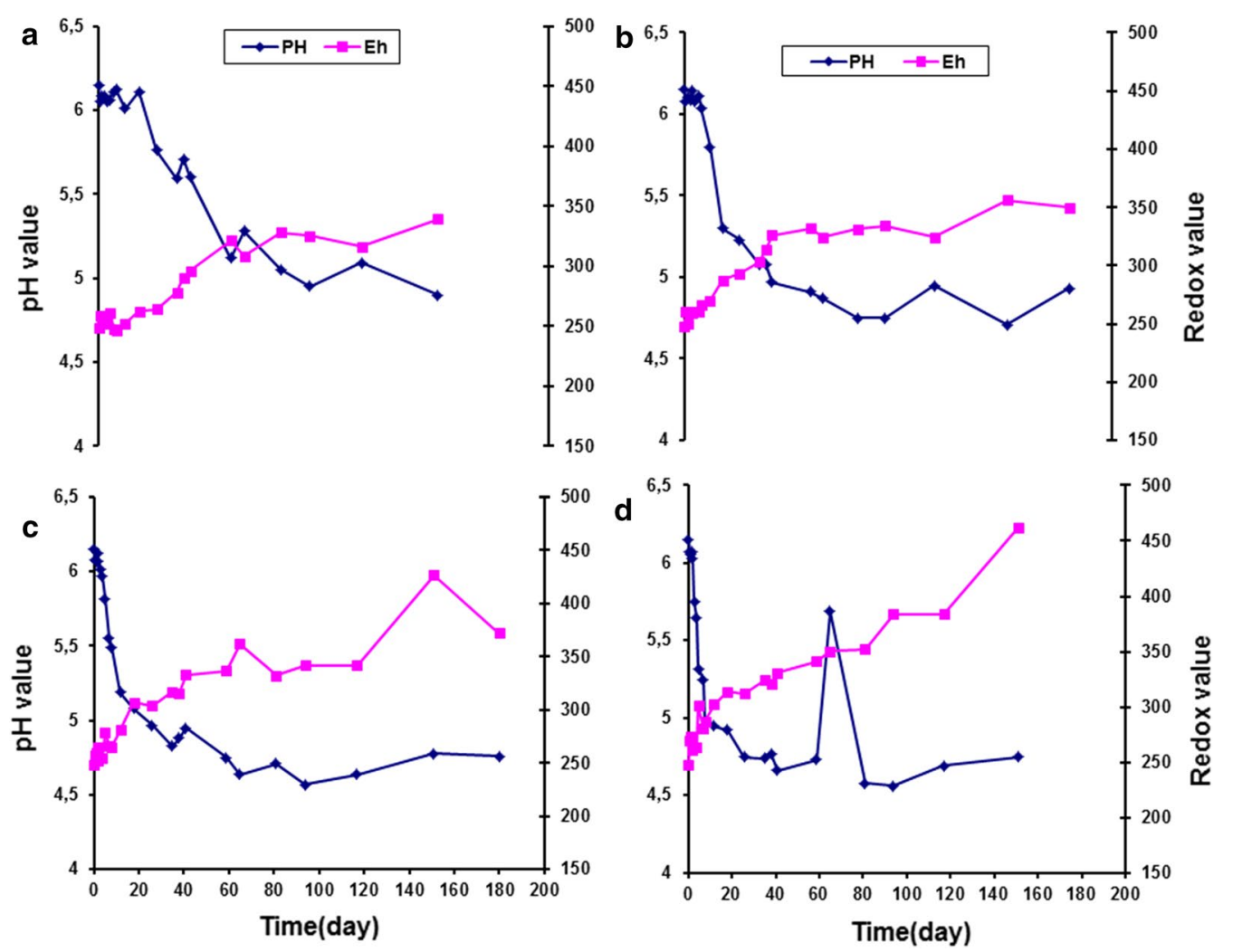

Fig. 7 Change of $\mathrm{pH}$ and redox values of modified atmosphere packaging smoked turkey with essential oil and stored at $\mathbf{a}, 0^{\circ} \mathrm{C} ; \mathbf{b}, 5^{\circ} \mathrm{C} ; \mathbf{c}, 10^{\circ} \mathrm{C}$ and $\mathbf{d}, 15^{\circ} \mathrm{C}$

Results assured that the inhibition of L. monocytogenes in RTE smoked turkey under MAP and MAPEO (at 0 and $5{ }^{\circ} \mathrm{C}$ ) was enhanced compared to VP during the shelf life of the product. The MAPEO system could be efficiently used to control the growth of the pathogen when strict temperature control is difficult as during processing, transportation, retail display, or home use. By contrast, VP under different temperatures allowed for multiplication of the pathogen, with $1-3 \log _{10} \mathrm{CFU} / \mathrm{g}$.

\section{Authors' contributions}

All authors shared equally in this work. All authors read and approved the final manuscript.

\section{Author details}

${ }^{1}$ Microbiology Department, Faculty of Agriculture, Zagazig University, Zagazig 44511, Egypt. ${ }^{2}$ Botany and Microbiology Department, Faculty of Science, Zagazig University, Zagazig 44511, Egypt. ${ }^{3}$ Poultry Department, Faculty of Agriculture, Zagazig University, Zagazig 44511, Egypt. ${ }^{4}$ Department of Veterinary Public Health and Animal Husbandry, College of Veterinary Medicine, King Faisal University, Hofuf, Saudi Arabia. ${ }^{5}$ Food Control Department, Faculty of Veterinary Medicine, Zagazig University, Zagazig, Egypt. ${ }^{6}$ Department of Animal Production, College of Food and Agricultural Sciences, King Saud University, P.O Box 2460, Riyadh 11451, Saudi Arabia. ${ }^{7}$ Department of Theriogenology, Faculty of Veterinary Medicine, Zagazig University, Zagazig 44519, Egypt.

\section{Acknowledgements}

The authors extend their appreciation to the Deanship of Scientific Research at King Saud University for funding this work through a research group project \# (RGP-267). The authors thank the Deanship of Scientific Research and RSSU at King Saud University for their technical support. Authors fully acknowledge Prof. George John-Nychas and the research team of Lab. Microbiology and Biotechnology of Foods, Department of Food Science and Human Nutrition, Era Odos 75, Athens 11855, Greece for their support to Dr. Samir Mahgoub. Authors extend thanks to their respected institutes and universities.

\section{Competing interests}

The authors declare that they have no competing interests.

\section{Availability of data and materials}

Not applicable.

\section{Consent for publication}

Not applicable.

\section{Ethics approval and consent to participate}

No live animals were used in the study.

\section{Funding}

This work was financially supported by the Deanship of Scientific Research at King Saud University through a research group Project No. (RGP-267).

\section{Publisher's Note}

Springer Nature remains neutral with regard to jurisdictional claims in published maps and institutional affiliations. 
Received: 7 March 2019 Accepted: 9 April 2019

Published online: 19 April 2019

\section{References}

Allerberger F (2003) Listeria: growth, phenotypic differentiation and molecular microbiology. FEMS Immun Med Microbiol 35:183-189

Aureli P, Costantini A, Zolea S (1992) Antimicrobial activity of some plant essential oils against Listeria monocytogenes. J Food Prot 55:344-348

Avery SM, Rogers AR, Bell RG (1995) Continued inhibitory effect of carbon dioxide packaging on Listeria monocytogenes and other microorganisms on normal pH beef during abusive retail display. Int J Food Sci Technol 30:725-735

Burt S (2004) Essential oils: their antibacterial properties and potential applications in foods - a review. J Food Microbiol 94:223-253

Burt SA, Reinders RD (2003) Antimicrobial activity selected plant essential oils against Escherichia coli 0157:H7. Lett Appl Microbiol 36:162-167

Farber JM, Daley E (1994) Fate of Listeria monocytogenes on modified atmosphere packaged turkey roll slices. J Food Protect 57:1098-1100

Gounadaki AS, Skandamis PN, Drosinos EH, Nychas G-JE (2007) Effect of packaging and storage temperature on the survival of Listeria monocytogenes inoculated postprocessing on sliced salami. J Food Prot 70(10):2313-2320

Grau FH, Vanderlinde PB (1990a) Growth of Listeria monocytogenes vacuumpackaged beef. J Food Prot 53:739-741

Grau FH, Vanderlinde PB (1990b) Growth of Listeria monocytogenes on vacuum-packaged beef. J Food Prot 53(9):739-741

Hao YY, Brackett RE, Doyle MP (1998a) Efficacy of plant extract inhibiting Aeromonas hydrophila and Listeria monocytogenes in refrigerated cooked poultry. Food Microbiol 15(4):367-378

Hao YY, Brackett RE, Doyle MP (1998b) Inhibition of Listeria monocytogenes and Aeromonas hydrophila by plant extracts in refrigerated cooked beef. J Food Prot 61(3):307-312

Holley RA, Patel D (2005) Improvement in shelf-life and safety of perishable foods by plant essential oils and smoke antimicrobials. Food Microbiol 22:273-292

Kalemba D, Kunicka A (2003) Antibacterial and antifungal properties of essential oils. Curr Med Chem 10:813-829
Lambert RJW, Skandamis P, Coote P, Nychas GJE (2001) A study of the minimum inhibitory concentration and mode of action of oregano essential oil thymol and carvacrol. J Appl Microbiol 91:453-462

Mead GC (2004) Microbiological quality of poultry meat: a review. Braz J Poult Sci 6(3):135-142

Midgley D, Torrance K (1978) Pot water anal. Wiley, New York

Mytle N, Anderson GL, Doyle MP, Smith MA (2006) Antimicrobial activity of clove (Syzygium aromaticum) oil in inhibiting Listeria monocytogenes on chicken frankfurters. Food Control 17:102-107

Oussalah M, Caillet S, Lacroix M (2006) Mechanism of action of Spanish oregano, Chinese cinnamon, and savory essential oils against cell membranes and walls of Escherichia coli O157:H7 and Listeria monocytogenes. J Food Prot 69:1046-1055

Porto ACS, Franco BDGM, Sant'Anna ES, Call JE, Piva A, Luchansky JB (2002) Viability of a five-strain mixture of Listeria monocytogenes in vacuumsealed packages of Frankfurters, commercially prepared with and without $2.0 \%$ or $3.0 \%$ added potassium lactate, during extended at 4 and $10^{\circ} \mathrm{C}$. J Food Prot $65: 308-315$

Possas A, Posada-Izquierdo GD, Pérez-Rodríguez F, Valero A, García-Gimeno RM, Duarte MCT (2017) Application of predictive models to assess the influence of thyme essential oil on Salmonella Enteritidis behaviour during shelf life of ready-to-eat turkey products. Int J Food Microbiol 240(2):40-46

Rutherford TJ, Marshall DL, Andrews LS, Coggins PC, Schilling MW, Gerard P (2007) Combined effect of packaging atmosphere and storage temperature on growth of Listeria monocytogenes on ready-to-eat shrimp. Food Microbiol 24:703-710

Samelis J, Bedie GK, Sofos JN, Belk KE, Scanga JA, Smith GC (2002) Control of Listeria monocytogenes with combined antimicrobials after post-process contamination and extended storage of Frankfurters at $4{ }^{\circ} \mathrm{C}$ in vacuum packages. J Food Prot 65:299-307

Ultee A, Bennik MHJ, Moezelaar R (2002) The phenolic hydroxyl group of carvacrol is essential for action against food-borne pathogen Bacillus cereus. Appl Environ Microbiol 68:1561-1568

U.S. Department of Agriculture, Food Safety and Inspection Service (2004) Compliance guidelines to control Listeria monocytogenes in post-lethality exposed ready-to-eat meat and poultry products. http://www.fsis.usda. gov/OPPDE/rdad/FRPubs/97-013F/CompGuidelines.pdf

\section{Submit your manuscript to a SpringerOpen ${ }^{\odot}$ journal and benefit from:}

- Convenient online submission

- Rigorous peer review

- Open access: articles freely available online

- High visibility within the field

Retaining the copyright to your article

Submit your next manuscript at springeropen.com 